Apidologie, 1987, 18 (2), 179-196

\title{
IMPROVED SIMPLE TECHNIQUES FOR IDENTIFYING AFRICANIZED AND EUROPEAN HONEY BEES
}

\author{
Thomas E. RINDERER ', H. Allen SYLVESTER ', \\ Steven M. BUCO ${ }^{2}$, Vicki A. LANCASTER ${ }^{2}$, Elton W. HERBERT ${ }^{3}$, \\ Anita M. COLLINS ${ }^{1}$ and Richard L. HELLMICH II ${ }^{1}$ \\ with the technical collaboration of \\ G. Lorraine DAVIS ' and Daniel WINFREY' \\ 1. United States Department of Agriculture, Agricultural Research Service, \\ Honey-Bee Breeding, Genetics, and Physiology Laboratory, \\ 1157 Ben Hur Road, Baton Rouge, Louisiana 70820, USA \\ and \\ 2. Department of Experimental Statistics, Louisiana State University, \\ Baton Rouge, Louisiana, 70893, USA \\ and \\ 3. USDA, ARS, Agricultural Research Center, Beneficial Insects Laboratory, \\ Beltsville, Maryland 20705, USA
}

\begin{abstract}
SUMMARY
Eight simple techniques based on discriminant statistical procedures are presented to identify Africanized and European bees in the Americas. These techniques are based on measurements of forewing lengths, the wet and dry weights of degastered bees, and femur lengths. Improved methodologies and statistical procedures result in many more correct identifications at high probabilities of class membership.
\end{abstract}

\section{INTRODUCTION}

The spread of Africanized bees in the Americas created a need within the apicultural community to have an accurate, inexpensive and rapid identification procedure to discriminate between Africanized and European honey bees. Initial work by DALY and BALLING (1978) produced a quality but time consuming method of identification based on the discriminant analysis of 25 morphometric characters. The speed of the method was improved considerably by using computer-assisted measurement (DALY et al., 1982). Nonetheless, the morphometric methods of DALY and his colleagues (loc. cit.), a different morphometric approach which measures a variety of wing characteristics (DALY and Hoelmer, pers. commun.), electrophoretic identification approaches (SyLVESTER, 1982), potential gas chromatographic approaches (CARLSON and Bol- 
TEN, 1984), potential DNA restriction approaches (G. Hall, W.S. ShePPARD, pers. commun.), and potential haemolymph protein approaches (B. Furgala, pers. commun.) all pose technical difficulties which restrict their use to wellequipped laboratories with highly trained personnel.

RINDERER et al. (1986 a) developed two simplified techniques appropriate for field-laboratory use. The simplest approach used a single character (forewing length) and correctly identified $86 \%$ of 136 colony samples at $\mathrm{P}>0.90$. The second approach used four morphometric measurements (forewing length, partial hindwing length, femur length and clean weight) and correctly identified $91 \%$ of colony samples at $\mathbf{P}>0.90$. There were no misidentifications with either procedure.

The procedures of Rinderer et al. (1986 a) were used in the recent regulatory quarantine when Africanized bees were found in California, USA (GARY et al., 1985). Approximately 25,000 colonies were identified before the quarantine was ended. These identifications were made during a 12-week period in $\mathrm{a}$ temporary laboratory using, for the most part, unskilled technical help. All dentifications of Africanized bees were confirmed using the procedures of )ALY et al. (1982). Periodically (two to four a day), quality-control samples of Africanized bees were placed as «blind» samples among the unknown samples being processed by the laboratory. Every quality-control sample was identified as Africanized.

Although the procedures of RINDERER et al. (1986 a) were successful in the California regulatory action, possible ways to improve the procedures became apparent. The chief difficulty was the preparation of bees for obtaining clean weights. This preparation required removing pollen, nectar and feces from bees. The unskilled workers had difficulty doing this correctly and uniformly. This paper presents improvements designed to circumvent this difficulty. Improvements in both methodology and statistical procedures have permitted the development of several alternate simple procedures to discriminate between Africanized and European bees.

\section{MATERIALS AND METHODS}

A collection of 40 bees was made from each of 86 colonies of Africanized bees in apiaries near Sarare, Venezuela. A similar collection was made from 100 colonies of European bees in apiaries near Baton Rouge, Louisiana ${ }^{(1)}$. Collections were made as described by RINDERER et al. (1986 a).

(1) The European honey bees in this study were from North America. Such bees have in their ancestry representatives of mixed subspecies. Africanized bees are descendants of A.m. scutellata bees imported from Africa and their hybrids with various subspecies previously imported into Brazil. Neither the European nor the the Africanized bees can correctly be called race, subspecies, stock, or line representatives. We use the term " geographical type " to indicate that the bees we studied showed major characteristics typical of descriptions for temperately or tropically (A.m. scutellata) adapted bees. 
Three groups of 10 bees from each colony were prepared for weighing by removing their pollen pellets, if present, and by removing their gasters. Gaster removal eliminated variance due to differing honey-sac and rectal contents. The three lots of 10 bees per colony were weighed as «fresh" bees immediately after gasters were removed (wet weight). Two lots of degastered bees were placed in a drying oven $\left(60^{\circ} \mathrm{C} ; 24 \mathrm{hrs}\right.$.) and again weighed (dry weight). One group of 10 bees from each colony was placed in $90 \%$ alcohol for at least 2 weeks. These bees were then removed from the alcohol, degastered, dried, and weighed (alcohol weight).

One group of bees providing wet weights was dissected and the field techniques described by Rinderer et al. (1986 a) were used to measure their forewing lengths, partial hindwing lengths and femur lengths.

An additional collection of bees was made from 30 Africanized colonies and 30 European colonies. These bees were frozen and air shipped to the Beneficial Insects Laboratory. There, the identification procedures using the univariate methods of wet weight, dry weight and forewing length were further evaluated using a double-blind protocol.

\section{ANALYSES AND RESULTS}

The six morphometric measurements (forewing length, partial hindwing length, femur-length, wet weight, dry weight, and alcohol weight) were first evaluated using univariate techniques (Table 1). Since the assumption of equal

TABL. 1. - Descriptive statistics and t-tests for means of forewing lengths, femur lengths, hindwing lengths, wet weights, dry weights and alcohol weights of European (E) and Africanized (A) bees

\begin{tabular}{l|l|l|l|l|l|l|l|l}
\hline \hline Race & $\mathbf{N}$ & Mean & Std. dev. & Range & Variances & $\mathrm{T}$ & Df & Prob \\
\hline
\end{tabular}

Forewing length

\begin{tabular}{l|r|r|r|r|l|l|l|l}
$\mathrm{E}$ & 100 & 9.281 & 0.078 & $9.098-9.460$ & Unequal & 41.31 & 155.1 & 0.0001 \\
$\mathrm{~A}$ & 84 & 8.715 & 0.103 & $8.412-8.950$ & &
\end{tabular}

Femur length

\begin{tabular}{|c|c|c|c|c|c|c|c|}
\hline 100 & 2.708 & 0.040 & $2.464-2.770$ & Equal & 32.95 & 182.0 & 0.0001 \\
\hline 84 & 2.531 & 0.033 & $2.440-2.614$ & & & & \\
\hline
\end{tabular}

Hindwing length
\begin{tabular}{l|r|}
$\mathrm{E}$ & 100 \\
$\mathrm{~A}$ & 84
\end{tabular}
\begin{tabular}{l|l}
4.380 & 0.053
\end{tabular}
$\left|\begin{array}{l}4.290-4.504 \\ 4.036-4.470\end{array}\right|$
Equal
\begin{tabular}{l|l|l}
24.98 & 182.0 & 0.0001
\end{tabular}

Wet weight
E
100
84
0.535
0.424
0.020
$\left|\begin{array}{c}0.488-0.576 \\ 0.365-0.477\end{array}\right|$

Equal
35.15
\begin{tabular}{l|l}
182.0 & 0.0001
\end{tabular}

Dry weight
E
100
84
0.171
0.145
0.006
0.009
$\left|\begin{array}{l}0.152-0.186 \\ 0.124-0.165\end{array}\right|$
Unequal
22.99
\begin{tabular}{l|l}
150.7 & 0.0001
\end{tabular}

Alcohol weight

\begin{tabular}{l|r|r|l|l|l|l|l|l}
$\mathbf{E}$ & 100 & 0.188 & 0.013 & $0.139-0.220$ & Unequal & 1.32 & 102.0 & 0.188 \\
$\mathrm{~A}$ & 84 & 0.183 & 0.035 & $0.136-0.274$ & & & & \\
\hline
\end{tabular}


variances for the $t$ statistic was violated by forewing length and dry weight data, df were calculated for these measures using SATTERWAITE's (1946) approximation. The means of Africanized and European bees were significantly different $(P>0.0001)$ for all the measurements except those of alcohol weights. After storage in alcohol, the range of weights of degastered Africanized bees included the range of weights of degastered European bees. Thus, alcohol weights were unable to aid in the discrimination between the two populations and were not further evaluated. The significant differences between the means of Africanized and European bees for the other five characteristics suggested that they each had some ability to contribute to the discrimination between Africanized and European bees.

Prior to doing multivariate analyses, an evaluation of the assumptions required for discriminant techniques was made. There were no missing data, and no outlying data. Evaluation of the assumptions of normality showed that the data were acceptable for the analyses. The correlations between the 5 variables were high, but since the purpose of the analyses was to determine which of the variables were the best discriminators, the high correlations were not judged a problem. A test for equality of the variance-covariance matrices of the discriminant functions (Kendall and StuarT, 1961) using Box's M showed them to be different at $\mathbf{P}>0.0001$. Therefore, observations were classified on the basis of separate variances of the discriminant functions.

A stepwise discriminant function analysis was performed (SPSS $\left.{ }^{\mathbf{x}^{(2)}}, 1983\right)$. This was done to identify which variables provided optimal discriminatory power. Wilk's lambda (TABACHNick and Fidell, 1983) was chosen as the stepping procedure. In agreement with prior analyses (RINDERER et al., 1986 a), forewing length best discriminated between the 2 populations. The other variables were ranked in discriminatory power as : wet weight $>$ femur length $>$ dry weight $>$ partial hindwing length. Because of its weak power to discriminate, partial hindwing length was not included in further analyses.

Since users of identification procedures may have different cost and technical requirements, eight different discriminant functions were developed $\left(\right.$ SPSS $^{x^{8(2)}}$, 1983) assuming equal prior probabilities of group membership. To develop each function, observations from the 84 Africanized colonies and 100 European colonies were randomly divided into 2 sets. The first set contained about $2 / 3$ of the observations (52 Africanized and 71 European). This set was used to develop initial discriminant functions and classification equations. The remaining observations (32 Africanized and 29 European) were used as a test set for cross-validation of the functions. Final functions and coefficients were derived from the data from the 84 Africanized and the 100 European colonies.

(2) SAS Institute, Inc., Cary, North Carolina and SPSS, Inc., Chicago, Illinois. Use of corporation names does not constitute an endorsement by the U.S. Dept. of Agriculture. 
In classification examinations of both the initial set and the test set the convention of an unidentified category was used (RINDERER et al., 1986 a). An observation not having a high probability of membership in either group was assigned to the unidentified category. The unidentified category is useful in this context since more elaborate procedures (DALY et al., loc. cit.) exist to closely examine samples which are listed as unidentified.

For all eight discriminant procedures, the formulae for calculating discriminant functions are presented in Table 2, and the formulae for calculating exact probabilities are presented in Table 3 .

TABL. 2. - Formulae for using measures * of forewing lengths, femur lengths, wet weights, and dry weights of unknown samples of bees either as single characteristics or combinations of characteristics to calculate the discriminant functions necessary to determine exact probabilities of group membership or to use tables 5 to 12

Forewing length

Function $=-99.88344+(11.07056 *$ Forewing length $)$.

Dry weight

Function $=-21.38278+(134.7200 *$ Dry weight $)$.

Wet weight

Function $=-22.72551+(46.89246 *$ Wet weight $)$.

Forewing length and dry weight

Function $=-94.05033+(9.743772 *$ Forewing length $)+$ $\left(38.67016^{*}\right.$ Dry weight).

Forewing length and wet weight

Function $=-84.29824+(8.011922 *$ Forewing length $)+$ $(24.78413 *$ Wet weight).

Forewing length and femur length

Function $=-104.4224+(8.541461 *$ Forewing length $)+$ $(10.41325 *$ Femur length).

Forewing length, femur length and dry weight

Function $=-99.41456+(7.570760 *$ Forewing length $)+$ $(9.683385 *$ Femur weight $)+$ $\left(34.04723{ }^{*}\right.$ Dry weight.

Forewing length, femur length and wet weight

Function $=-89.41456+(6.601482 *$ Forewing length $)+$ $(7.234500 *$ Femur weight $)+$ $(22.38143 *$ Wet weight).

* Forewing length is the average measurement for 10 bees ;

Femur length is the average measurement for 10 bees;

Wet weight is the average weight for three groups of 10 bees each ;

Dry weight is the average weight for three groups of 10 bees each. 
TABL. 3. - Formulae for calculating exact probabilities of group membership in Africanized populations (PA) and European populations (PE) using functions derived from body-part measures according to formulae in Table 2

In all cases

$P A=e^{-0.5 *} D_{A}^{2} /\left(e^{-0.5 *} D_{A}^{2}+e^{-0.5 *} D_{E}^{2}\right)$

and

$\mathbf{P E}=1-\mathbf{P A}$

Forewing length

$\left.\mathrm{D}_{\mathrm{A}}^{2}=\{\text { (Function }+3.40129)^{2} / 1.296522\right\}+0.259685$

$D_{\mathrm{E}}^{2}=\left\{(\text { Function }-2.85709)^{2} / 0.751400\right\}-0.285816$

Dry weight

$\left.D_{\mathrm{A}}^{2}=\{\text { (Function }+1.89649)^{2} / 1.321694\right\}+0.278915$

$D_{E}^{2}=\left\{(\text { Function }-1.59305)^{2} / 0.730296\right\}-0.314305$

Wet weight

$\mathrm{D}_{\mathrm{A}}^{2}=\left\{(\text { Function }+2.82785)^{2} / 1.130935\right\}+0.123045$

$D_{\mathrm{E}}^{2}=\left\{(\text { Function }-2.37540)^{2} / 0.890225\right\}-0.116280$

Forewing length and dry weight

$\left.\mathrm{D}_{\mathrm{A}}^{2}=\{\text { (Function }+3.53802)^{2} / 1.287209\right\}+0.252477$

$D_{\mathrm{E}}^{2}=\left\{(\text { Function }-2.97194)^{2} / 0.759208\right\}-0.275479$

Forewing length and wet weight

$\mathrm{D}_{\mathrm{A}}^{2}=\left\{(\text { Function }+3.95617)^{2} / 1.235027\right\}+0.211093$

$\mathrm{D}_{\mathrm{E}}^{2}=\left\{(\text { Function }-3.32319)^{2} / 0.802957\right\}-0.219454$

Forewing length and femur length

$\mathrm{D}_{\mathrm{A}}^{2}=\left\{(\text { Function }+3.62363)^{2} / 1.287078\right\}+0.252375$

$\mathrm{D}_{\mathrm{E}}^{2}=\left\{(\text { Function }-3.04850)^{2} / 0.759317\right\}-0.275335$

Forewing length, dry weight and femur length

$\mathrm{D}_{\mathrm{A}}^{2}=\left\{(\text { Function }+3.73463)^{2} / 1.288703\right\}+0.253637$

$\left.\mathrm{D}_{\mathrm{E}}^{2}=\{\text { (Function }-3.13709)^{2} / 0.757966\right\}-0.277116$

Forewing length, wet weight and femur length

$\mathrm{D}_{\mathrm{A}}^{2}=\left\{(\text { Function }+4.07224)^{2} / 1.248415\right\}+0.221875$

$D_{\mathrm{E}}^{2}=\left\{(\text { Function }-3.42068)^{2} / 0.791732\right\}-0.233532$

\section{Forewing Length}

With the criterion that the posterior probability of a sample belonging to a group exceed 0.99 to be declared a member of that group, all of the samples were correctly identified with forewing length measures. Consequently, fore- 

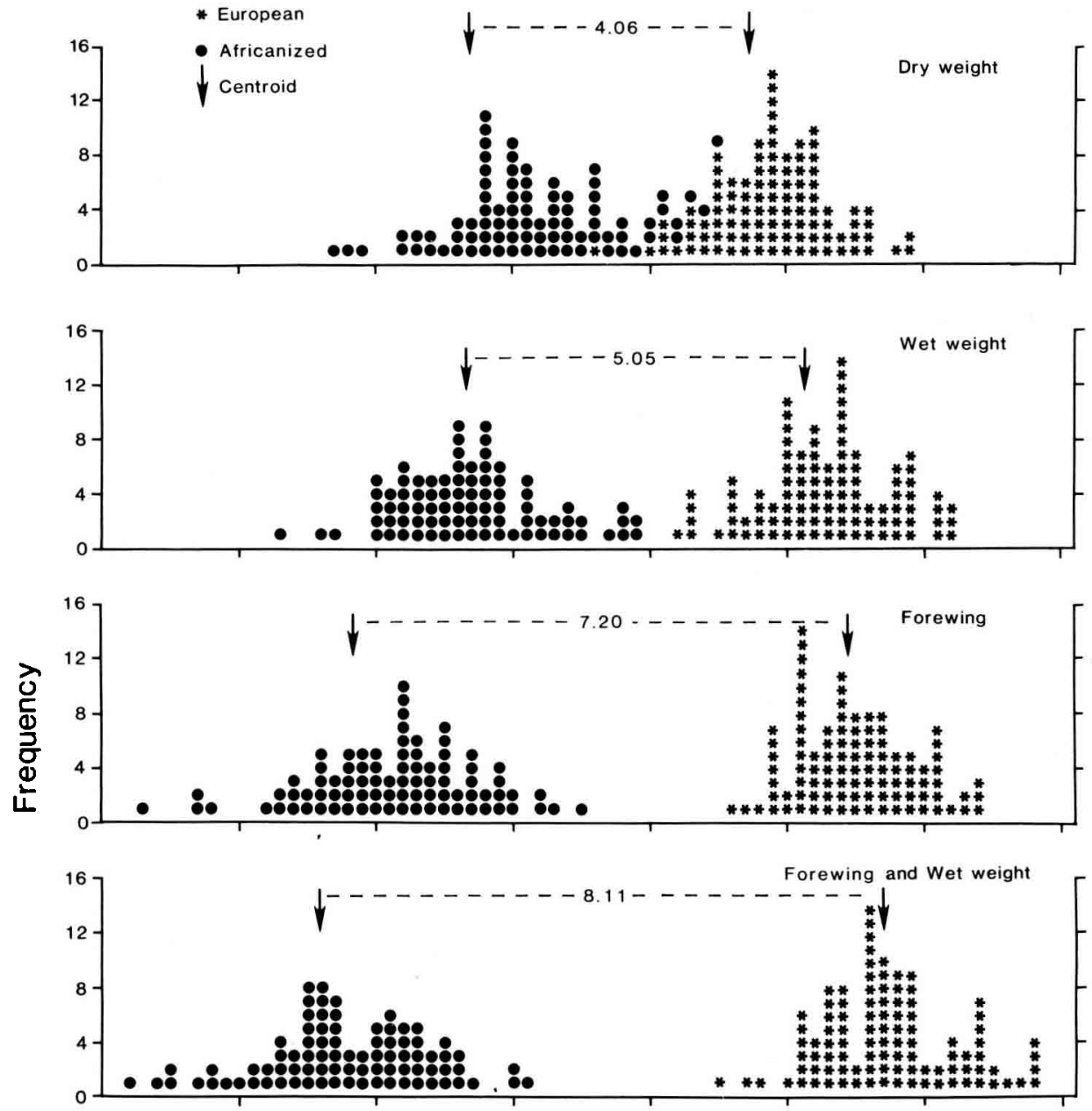

Forewing, Wet weight and Femur

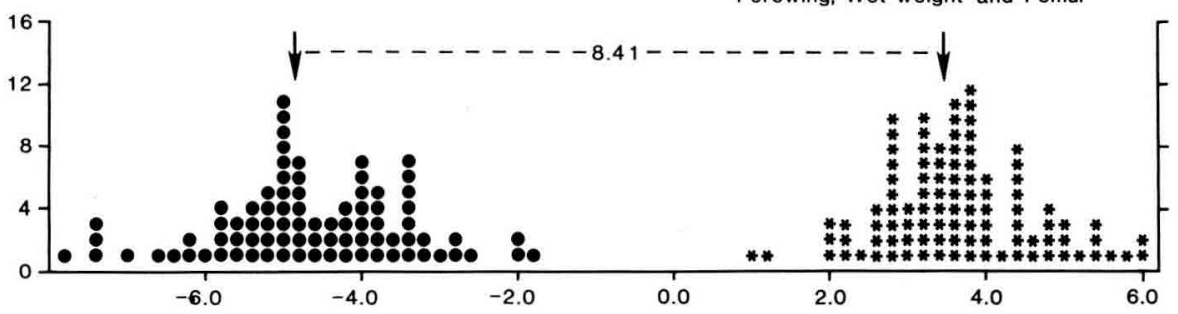

Discriminant Axis

FIG. 1. - Histograms of the placement of individual observations on a common discriminant axis for dry weights, wet weights, forewing lengths, the combination of forewing lengths and wet weights and the combination of forewing lengths, wet weights, and femur lengths.

Numbers between arrows indicate the distance between group centroids. 
wing length in combination with any other characteristic correctly identified all samples using a posterior probability criterion of $P>0.99$ (Table 4). Thus, the classification tables are of no value in comparing the relative strengths of the procedures which involve forewing length. A different way to compare the relative strengths of the procedures is to compare the distance of the Africanized centroid from the European centroid using the distance function of the European group. The distance between group centroids for the forewing procedure is 7.20 (Fig. 1).

TABL. 4. - Classification results [number of samples (percentage of samples)] for cases selected to develop and then test the discriminant analyses listed in Table 1.

Group memberships are Africanized (A), European (E), and unidentified (U)

\begin{tabular}{|c|c|c|c|c|c|}
\hline \multicolumn{6}{|c|}{ ANALYSIS CATEGORY } \\
\hline \multirow{2}{*}{$\begin{array}{c}\text { Probability } \\
\text { of Classification }\end{array}$} & \multirow{2}{*}{$\begin{array}{l}\text { Actual } \\
\text { Group }\end{array}$} & \multirow{2}{*}{$\begin{array}{l}\mathbf{N}^{\circ} \text { of } \\
\text { Cases }\end{array}$} & \multicolumn{3}{|c|}{ Predicted Group Membership } \\
\hline & & & A & $\mathrm{E}$ & $\mathrm{U}$ \\
\hline \multicolumn{6}{|c|}{ All analyses using forewing lengths } \\
\hline Development & & & & & \\
\hline 0.99 & $\begin{array}{l}\mathrm{A} \\
\mathrm{E}\end{array}$ & $\begin{array}{l}52 \\
71\end{array}$ & $\begin{array}{c}52(100.00) \\
0\end{array}$ & $\begin{array}{c}0 \\
67(100.00)\end{array}$ & $\begin{array}{l}0 \\
0\end{array}$ \\
\hline 0.99 & $\begin{array}{l}\mathrm{A} \\
\mathrm{E}\end{array}$ & $\begin{array}{l}29 \\
32\end{array}$ & $\begin{array}{c}29(100.00) \\
0\end{array}$ & $\begin{array}{c}0 \\
32(100.00)\end{array}$ & $\begin{array}{l}0 \\
0\end{array}$ \\
\hline
\end{tabular}

Dry weight

\begin{tabular}{|c|c|c|c|c|c|}
\hline \multicolumn{6}{|l|}{ Development } \\
\hline \multirow[t]{2}{*}{0.70} & A & 52 & $47(90.38)$ & $3(5.77)$ & $2(3.85)$ \\
\hline & $\mathrm{E}$ & 71 & $1(1.41)$ & $66(92.96)$ & $4(5.63)$ \\
\hline \multirow[t]{2}{*}{0.90} & A & 52 & $45(86.54)$ & $1(1.92)$ & $6(11.54)$ \\
\hline & $\mathrm{E}$ & 71 & $1(1.41)$ & $62(87.32)$ & $8(11.27)$ \\
\hline \multirow[t]{2}{*}{0.95} & A & 52 & $43(82.69)$ & 0 & $9(17.31)$ \\
\hline & $E$ & 71 & $1(1.41)$ & $59(83.10)$ & $11(15.49)$ \\
\hline \multirow[t]{2}{*}{0.99} & A & 52 & $40(76.92)$ & 0 & $12(23.08)$ \\
\hline & $E$ & 71 & 0 & $48(67.61)$ & $23(32.39)$ \\
\hline \multicolumn{6}{|l|}{ Test } \\
\hline \multirow[t]{2}{*}{0.70} & A & 32 & $30(93.75)$ & 0 & $2(6.25)$ \\
\hline & $E$ & 29 & $1(3.45)$ & $28(96.55)$ & 0 \\
\hline \multirow[t]{2}{*}{0.90} & A & 32 & $29(90.62)$ & 0 & $3(9.38)$ \\
\hline & $\mathrm{E}$ & 29 & 0 & $21(72.41)$ & $8(27.59)$ \\
\hline \multirow[t]{2}{*}{0.95} & A & 32 & $28(87.50)$ & 0 & $4(12.50)$ \\
\hline & $E$ & 29 & 0 & $19(65.52)$ & $10(34.48)$ \\
\hline \multirow[t]{2}{*}{0.99} & A & 32 & $23(71.88)$ & 0 & $9(28.12)$ \\
\hline & $\mathrm{E}$ & 29 & 0 & $12(41.38)$ & $17(58.62)$ \\
\hline
\end{tabular}


Wet weight

\begin{tabular}{|c|c|c|c|c|c|}
\hline \multicolumn{6}{|l|}{ Development } \\
\hline \multirow[t]{2}{*}{0.70} & A & 52 & $52(100.00)$ & 0 & 0 \\
\hline & E & 71 & 0 & $71(100.00)$ & 0 \\
\hline \multirow[t]{2}{*}{0.90} & A & 52 & $51(98.08)$ & 0 & $1(1.92)$ \\
\hline & $\mathrm{E}$ & 71 & 0 & $68(95.72)$ & $3(4.23)$ \\
\hline \multirow[t]{2}{*}{0.95} & A & 52 & $51(98.08)$ & 0 & $1(1.92)$ \\
\hline & E & 71 & 0 & $68(95.77)$ & $3(4.23)$ \\
\hline \multirow[t]{2}{*}{0.99} & A & 52 & $49(94.23)$ & 0 & $3(5.77)$ \\
\hline & $\mathrm{E}$ & 71 & 0 & 68 (95.77) & $3(4.23)$ \\
\hline \multicolumn{6}{|l|}{ Test } \\
\hline \multirow[t]{2}{*}{0.70} & A & 32 & $32(100.00)$ & 0 & 0 \\
\hline & E & 29 & 0 & $29(100.00)$ & 0 \\
\hline \multirow[t]{2}{*}{0.90} & A & 32 & $32(100.00)$ & 0 & 0 \\
\hline & E & 29 & 0 & $28(96.55)$ & $1(3.45)$ \\
\hline \multirow[t]{2}{*}{0.95} & A & 32 & $31(96.88)$ & 0 & $1(3.12)$ \\
\hline & E & 29 & 0 & $27(93.10)$ & $2(6.90)$ \\
\hline \multirow[t]{2}{*}{0.99} & A & 32 & $30(93.75)$ & 0 & $2(6.25)$ \\
\hline & E & 29 & 0 & $27(93.10)$ & $2(6.90)$ \\
\hline
\end{tabular}

Probabilities of group memberships for selected forewing lengths and their corresponding discriminant functions are presented in Table 5. The forewing discriminant procedure is improved from the procedure presented by RINDERER et al. (1986 a) in that the function is adjusted to accommodate the unequal variances of the two populations. Combining the present data and those of RINDERER et al. (1986 a), the new procedure correctly identified $304(95.0 \%)$ of the 320 samples at $P>0.99$ and left the remaining $16(5.0 \%)$ samples unclassified. At $\mathrm{P}>0.90$ the new procedure correctly identified $308(96.3 \%)$ of the 320 samples, did not classify $10(3.1 \%)$ samples and misclassified 2 $(0.6 \%)$ samples, one of them European and the other Africanized. The older procedure correctly identified $224(70 \%)$ of the 320 samples at $\mathrm{P}>0.99$ while the remaining $96(30 \%)$ were unclassified. At $\mathrm{P}>0.90$ the older procedure correctly identified $291(90.9 \%)$ and left the remaining $29(9.1 \%)$ unidentified. Thus, the newer method has improved exactness. It can be used with higher probabilities required for positive identifications and yet it will produce a greater frequency of positive and correct identifications.

At $\mathbf{P}>0.99$ all of the cross-fostered Africanized bees studied by RINDERER $e$ t al. (1986 b) would be identified as Africanized by the newer forewing procedure. Of the European bees, only those reared in Africanized sized comb would be unclassified by the procedure. The other groups of European bees in that study would all be classified as European at $\mathrm{P}>0.99$. 
TABL. 5. - Probability table for averages of 10 forewing lengths and the corresponding forewing length discriminant function

\begin{tabular}{c|c|c|c}
\hline \hline Forewing length $(\mathrm{mm})$ & Function & PA & PE \\
\hline 8.968 & -0.59729 & 0.99 & 0.01 \\
8.991 & -0.34329 & 0.95 & 0.05 \\
9.001 & -0.23129 & 0.90 & 0.10 \\
9.008 & -0.16129 & 0.85 & 0.15 \\
9.013 & -0.10729 & 0.80 & 0.20 \\
9.017 & -0.06129 & 0.75 & 0.25 \\
9.020 & -0.02329 & 0.70 & 0.30 \\
9.024 & 0.01271 & 0.65 & 0.35 \\
9.027 & 0.04671 & 0.60 & 0.40 \\
9.030 & 0.07871 & 0.55 & 0.45 \\
9.032 & 0.10871 & 0.50 & 0.50 \\
9.035 & 0.14071 & 0.45 & 0.55 \\
9.038 & 0.17271 & 0.40 & 0.60 \\
9.041 & 0.20671 & 0.35 & 0.65 \\
9.044 & 0.24271 & 0.30 & 0.70 \\
9.048 & 0.28271 & 0.25 & 0.75 \\
9.052 & 0.32871 & 0.20 & 0.80 \\
9.057 & 0.38471 & 0.15 & 0.85 \\
9.064 & 0.45871 & 0.10 & 0.90 \\
9.075 & 0.58071 & 0.05 & 0.95 \\
9.099 & 0.84871 & 0.01 & 0.99 \\
\hline
\end{tabular}

\section{Dry Weight}

Dry weight was the weakest univariate discriminator selected for possible use. The distance betwen group centroids was 4.06 ; only about half the distance between centroids in the forewing analysis (Fig. 1). The discriminatory weakness of dry weight is also reflected in the classification results (Table 4). Dry weight procedures resulted in several misclassifications when the criterion for classification was set as $\mathbf{P}>\mathbf{0 . 9 0}$ or below. Nonetheless, at $\mathbf{P}>0.99$, dry weight correctly classified $123(66.8 \%)$ of the 184 samples and left the remaining $61(33.2 \%)$ samples unclassified. Table 6 provides probabilities of group membership associated with selected dry weights and their corresponding discriminant functions.

\section{Wet Weight}

Wet weight is second only to forewing length as a univariate discriminator. There is a reasonably large distance between group centroids (5.05) and a lack of overlap between the two populations (Fig. 1). Overall, wet weight gave no misclassifications and only left $10(5.4 \%)$ samples out of 184 unclassified at P $>0.99$ (Table 4). Probabilities of group membership for selected wet weights and their corresponding discriminant functions are presented in Table 7. 
TABL. 6. - Probability table for the average of 2 groups of 10 dry weights and the corresponding dry weight discriminant function

\begin{tabular}{c|c|c|c}
\hline \hline Dry weight (grams) & Function & PA & PE \\
\hline 0.1503 & -1.12849 & 0.99 & 0.01 \\
0.1532 & -0.74249 & 0.95 & 0.05 \\
0.1545 & -0.55849 & 0.90 & 0.10 \\
0.1554 & -0.44049 & 0.85 & 0.15 \\
0.1561 & -0.35049 & 0.80 & 0.20 \\
0.1566 & -0.27449 & 0.75 & 0.25 \\
0.1571 & -0.20849 & 0.70 & 0.30 \\
0.1576 & -0.14649 & 0.65 & 0.35 \\
0.1580 & -0.09049 & 0.60 & 0.40 \\
0.1584 & -0.03449 & 0.55 & 0.45 \\
0.1593 & 0.07951 & 0.50 & 0.50 \\
0.1596 & 0.12151 & 0.45 & 0.55 \\
0.1597 & 0.13551 & 0.40 & 0.60 \\
0.1601 & 0.19751 & 0.35 & 0.65 \\
0.1606 & 0.26351 & 0.30 & 0.70 \\
0.1612 & 0.33551 & 0.25 & 0.75 \\
0.1618 & 0.42151 & 0.20 & 0.80 \\
0.1626 & 0.52551 & 0.15 & 0.85 \\
0.1636 & 0.66751 & 0.10 & 0.90 \\
0.1654 & 0.90751 & 0.05 & 0.95 \\
0.1695 & 1.46151 & 0.01 & 0.99 \\
\hline
\end{tabular}

TABL. 7. - Probability table for the average of 3 groups of 10 wet weights and the corresponding wet weight discriminant function

\begin{tabular}{c|c|c|c}
\hline \hline Wet weight (grams) & Function & PA & PE \\
\hline 0.4639 & -0.96985 & 0.99 & 0.01 \\
0.4707 & -0.65185 & 0.95 & 0.05 \\
0.4737 & -0.51385 & 0.90 & 0.10 \\
0.4755 & -0.42585 & 0.85 & 0.15 \\
0.4770 & -0.35985 & 0.80 & 0.20 \\
0.4781 & -0.30585 & 0.75 & 0.25 \\
0.4792 & -0.25585 & 0.70 & 0.30 \\
0.4800 & -0.21385 & 0.65 & 0.35 \\
0.4810 & -0.17185 & 0.60 & 0.40 \\
0.4819 & -0.13185 & 0.55 & 0.45 \\
0.4826 & -0.09385 & 0.50 & 0.50 \\
0.4834 & -0.05585 & 0.45 & 0.55 \\
0.4849 & -0.01585 & 0.40 & 0.60 \\
0.4852 & 0.02615 & 0.35 & 0.65 \\
0.4861 & 0.07015 & 0.30 & 0.70 \\
0.4872 & 0.11815 & 0.25 & 0.75 \\
0.4883 & 0.17615 & 0.20 & 0.80 \\
0.4897 & 0.24215 & 0.15 & 0.85 \\
0.4917 & 0.33415 & 0.10 & 0.90 \\
0.4948 & 0.48015 & 0.05 & 0.95 \\
0.5017 & 0.80415 & 0.01 & 0.99 \\
\hline
\end{tabular}




\section{Forewing Length and Dry Weight}

The group centroids for the forewing length and dry weight procedure differ by 7.45 on the discriminant scale. Probabilities of group membership for selected functions of combinations of forewing length and dry weight are presented in Table 8 .

TABL. 8. - Probability table for the forewing length and dry weight discriminant function

\begin{tabular}{c|c|c}
\hline \hline Function & PA & PE \\
\hline-0.58002 & 0.99 & 0.01 \\
-0.33402 & 0.95 & 0.05 \\
-0.22602 & 0.90 & 0.10 \\
-0.15602 & 0.85 & 0.15 \\
-0.10402 & 0.80 & 0.20 \\
-0.06002 & 0.75 & 0.25 \\
-0.02402 & 0.70 & 0.30 \\
0.00998 & 0.65 & 0.35 \\
0.04198 & 0.60 & 0.40 \\
0.07398 & 0.55 & 0.45 \\
0.10398 & 0.50 & 0.50 \\
0.13598 & 0.45 & 0.55 \\
0.16598 & 0.40 & 0.60 \\
0.19798 & 0.35 & 0.65 \\
0.23398 & 0.30 & 0.70 \\
0.27398 & 0.25 & 0.75 \\
0.31598 & 0.20 & 0.80 \\
0.36998 & 0.15 & 0.85 \\
0.44198 & 0.10 & 0.90 \\
0.55798 & 0.05 & 0.95 \\
0.81398 & 0.01 & 0.99 \\
\hline \hline
\end{tabular}

Forewing Length and Wet Weight

The discriminant scale distance between group centroids for the forewing length and wet weight is 8.11 , which represents a substantial improvement over either characteristic as a univariate procedure (Fig. 1). Probabilities of group membership for selected functions of combinations of forewing length and dry weight are presented in Table 9.

\section{Forewing Length and Femur Length}

The forewing length and femur length procedure has a distance between group centroids of 7.64. Probabilities of group membership for the functions of this procedure are presented in Table 10. 
TABL. 9. - Probability table for the forewing length and wet weight discriminant function

\begin{tabular}{c|c|c}
\hline \hline Function & PA & PE \\
\hline-0.57617 & 0.99 & 0.01 \\
-0.35417 & 0.95 & 0.05 \\
-0.25427 & 0.90 & 0.10 \\
-0.19217 & 0.85 & 0.15 \\
-0.14417 & 0.80 & 0.20 \\
-0.10417 & 0.75 & 0.25 \\
-0.07017 & 0.70 & 0.30 \\
-0.04017 & 0.65 & 0.35 \\
-0.01017 & 0.60 & 0.40 \\
0.01783 & 0.55 & 0.45 \\
0.04383 & 0.50 & 0.50 \\
0.07183 & 0.45 & 0.55 \\
0.09983 & 0.40 & 0.60 \\
0.12983 & 0.35 & 0.65 \\
0.15983 & 0.30 & 0.70 \\
0.19583 & 0.25 & 0.75 \\
0.23383 & 0.20 & 0.80 \\
0.28383 & 0.15 & 0.85 \\
0.34783 & 0.10 & 0.90 \\
0.45183 & 0.05 & 0.95 \\
0.67983 & 0.01 & 0.99 \\
\hline
\end{tabular}

TABL. 10. - Probability table for the forewing length and femur length discriminant function

\begin{tabular}{c|c|c}
\hline \hline Function & PA & PE \\
\hline-0.55963 & 0.99 & 0.01 \\
-0.31963 & 0.95 & 0.05 \\
-0.21163 & 0.90 & 0.10 \\
-0.14563 & 0.85 & 0.15 \\
-0.09563 & 0.80 & 0.20 \\
-0.05363 & 0.75 & 0.25 \\
-0.01563 & 0.70 & 0.30 \\
0.01637 & 0.65 & 0.35 \\
0.04837 & 0.60 & 0.40 \\
0.07837 & 0.55 & 0.45 \\
0.10837 & 0.50 & 0.50 \\
0.13837 & 0.45 & 0.55 \\
0.16837 & 0.40 & 0.60 \\
0.20037 & 0.35 & 0.65 \\
0.23437 & 0.30 & 0.70 \\
0.27237 & 0.25 & 0.75 \\
0.31637 & 0.20 & 0.80 \\
0.36837 & 0.15 & 0.85 \\
0.43637 & 0.10 & 0.90 \\
0.55037 & 0.05 & 0.95 \\
0.80037 & 0.01 & 0.99 \\
\hline
\end{tabular}




\section{Forewing Length, Femur Length, and Dry Weight}

The group centroids using the three characteristics of forewing length, femur length, and dry weight in an analysis differ by 7.87 . Table 11 provides selected functions and their probabilities of group membership.

TABL. 11. - Probability table for the forewing length, dry weight and femur length discriminant function

\begin{tabular}{c|c|c}
\hline \hline Function & PA & PE \\
\hline-0.52063 & 0.99 & 0.01 \\
-0.29863 & 0.95 & 0.05 \\
-0.19463 & 0.90 & 0.10 \\
-0.12963 & 0.85 & 0.15 \\
-0.08063 & 0.80 & 0.20 \\
-0.04063 & 0.75 & 0.25 \\
-0.00463 & 0.70 & 0.30 \\
0.02837 & 0.65 & 0.35 \\
0.05837 & 0.60 & 0.40 \\
0.08737 & 0.55 & 0.45 \\
0.11637 & 0.50 & 0.50 \\
0.14537 & 0.45 & 0.55 \\
0.17437 & 0.40 & 0.60 \\
0.20537 & 0.35 & 0.65 \\
0.23837 & 0.30 & 0.70 \\
0.27437 & 0.25 & 0.75 \\
0.29937 & 0.20 & 0.80 \\
0.36737 & 0.15 & 0.85 \\
0.43537 & 0.10 & 0.90 \\
0.54537 & 0.05 & 0.95 \\
0.78737 & 0.01 & 0.99 \\
\hline
\end{tabular}

\section{Forewing Length, Femur Length, and Wet Weight}

The group centroids in the analysis of forewing length, femur length, and wet weight are separated by a distance of 8.41 (Fig. 1). Probabilities of group membership for the functions of this procedure are presented in Table 12.

\section{Double-Blind Results}

The additional samples identified in the double-blind test at the Beneficial Insects Laboratory confirmed the identification value of forewing lengths. Using the criterion of probability of group membership of $P>0.99$, the 30 
TABL. 12. - Probability table for the forewing length, wet weight and femur length discriminant function

\begin{tabular}{c|c|c}
\hline Function & PA & PE \\
\hline-0.53224 & 0.99 & 0.01 \\
-0.31624 & 0.95 & 0.05 \\
-0.22024 & 0.90 & 0.10 \\
-0.16024 & 0.85 & 0.15 \\
-0.11424 & 0.80 & 0.20 \\
-0.07624 & 0.75 & 0.25 \\
-0.04224 & 0.70 & 0.30 \\
-0.01224 & 0.65 & 0.35 \\
0.01576 & 0.60 & 0.40 \\
0.04176 & 0.55 & 0.45 \\
0.06776 & 0.50 & 0.50 \\
0.09576 & 0.45 & 0.55 \\
0.12176 & 0.40 & 0.60 \\
0.15176 & 0.35 & 0.65 \\
0.18176 & 0.30 & 0.70 \\
0.21576 & 0.25 & 0.75 \\
0.25376 & 0.20 & 0.80 \\
0.29976 & 0.15 & 0.85 \\
0.36176 & 0.10 & 0.90 \\
0.46376 & 0.05 & 0.95 \\
0.68376 & 0.01 & 0.99 \\
\hline
\end{tabular}

Africanized samples were correctly identified, 28 of the European samples were correctly identified and 2 European samples were classified as unidentified. Using the criterion of probability of group membership of $P>0.90$, all of the 60 samples were correctly identified by the forewing procedures.

Dry weight procedures using the $\mathrm{P}>0.99$ criterion correctly identified all the Africanized samples. Of the European samples, 26 were correctly identified and 4 were unclassified. Using the $P>0.90$ criterion, all of the samples were correctly identified by the dry weight procedures.

Wet weight procedures gave poor results. Using the $P>0.99$ criterion, 12 of the Africanized samples remained unidentified, 2 were misclassified and 16 were correctly identified. All 30 European samples were correctly identified. Using the $P>0.90$ criterion, all 30 European samples were correctly identified but five Africanized samples were misidentified. Of the remaining Africanized samples, 16 were correctly identified and 9 remained unclassified. 


\section{DISCUSSION}

These procedures represent several improvements of the techniques for identifying Africanized and European bees presented by Rinderer et al. (1986 a). "Clean weight " is replaced by either wet or dry weights of degastered bees. This dissection is very simple. Only if body parts other than the gaster are removed during dissection can the dissection be done incorrectly. The preparation of degastered bees also requires the removal of pollen pellets if they are present. This procedure is also very simple. The precision obtained by using weights from degastered bees, in combination with the greater accuracy derived from using statistical procedures which accommodate unequal variances results in substantially improved numbers of correct identifications at high probabilities of group membership.

Because of the improved accuracy of these techniques, persons interested in discriminating Africanized from European bees now have several choices of identification procedures. Depending upon program needs, capabilities, and equipment availability, any of three univariate procedures can be selected as a preliminary identification tool. Since forewing length is the best univariate discriminator and wet weight is next best, either of these measures would be especially useful as initial screening tools. The results of the blind test suggest that freezing and transport reduce the discriminatory value of wet weight. Apparently, all the samples become heavier because of the freezing, thawing, and associated water condensation. This led to several misidentifications. Where wet weights are used, only freshly killed bees can be expected to give satisfactory results. Dry weight overcomes these technical difficulties in maintaining accurate body moisture for the wet weight. Thus, in spite of its lower discriminatory power, dry weight may be useful as an initial screening tool for larger regulatory programs or in programs where transportation of samples is difficult.

For all univariate analyses, at least a few samples may remain unidentified after identification procedures with a univariate discriminator. Any of three bivariate or two trivariate procedures can be used to identify samples not classified by univariate procedures.

The best bivariate procedure combines forewing length and wet weight. The major disadvantage of this procedure is that it requires equipment to measure both lengths and weights. Beyond that, it is the simplest and fastest bivariate procedure. The bivariate procedure involving forewing and femur lengths may prove desirable in cases where only equipment to measure lengths is available. This procedure is the second best bivariate approach. Where dry weight was used as an initial screening tool, the most useful bivariate procedure would be the addition of forewing length. 
Femur lengths contribute to the discriminatory powers of forewing length, wet weight, and dry weight. We therefore present two trivariate procedures (forewing length, femur length, and dry weight ; forewing length, femur length and wet weight) since large programs may have a need for these analyses. The most precise of these trivariate discriminant procedures (forewing length, femur length and wet weight) gives the best separation of Africanized and European populations using these simple methods (Fig. 1).

The improved precision of these techniques does necessitate a caveat. Ideally, users should verify that the European bees in their area are similar to the European bees in this study before these procedures are used to detect Africanization. If the European bees are not similar, especially if they are smaller, locally collected baseline data should be used to develop new discriminant functions or at least be considered in evaluating results. Such new functions would be more appropriate to the user's needs.

Received for publication in July 1986. Accepted for publication in September 1986.

\title{
ACKNOWLEDGEMENT
}

In cooperation with the Louisiana Agricultural Experiment Station.

\author{
RÉSUMÉ \\ TECHNIQUES SIMPLES AMÉLIOREES D'IDENTIFICATION \\ DES ABEILLES AFRICANISÉES ET EUROPÉENNES
}

On décrit une technique rapide, précise et non coûteuse pour différencier en Amérique du Sud et du Nord les abeilles africanisées des abeilles européennes. Les mesures et statistiques ont été améliorées par rapport à l'ancienne version de Rinderer et al. (1986 a). Cette méthode utilise les paramètres suivants : longueur de l'aile antérieure, "poids humide " (ouvrière moins l'intestin), " poids sec » (ouvrière moins l'intestin, séchée $24 \mathrm{~h}$ à $60^{\circ} \mathrm{C}$ ), soit individuellement, soit en combinaison; ou bien en combinaison avec la longueur du fémur. Les données statistiques relatives à ces mesures sont données dans le Tableau 1. Le pouvoir discriminant des mesures individuelles est le suivant : longueur de l'aile antérieure $>$ poids humide $>$ longueur du fémur $>$ poids sec. Les combinaisons sont encore plus discriminantes, ainsi que le montre la séparation des centroïdes de groupes pour les cas sélectionnés (Fig. 1).

On a mis au point 8 fonctions discriminantes différentes pour permettre aux utilisateurs de choisir la mesure ou la combinaison qui convient le mieux à leurs besoins et leurs possibilités. Les formules de calcul de ces fonctions sont données dans le tableau 2 et les formules de calcul des probabilités exactes de l'appartenance à l'un des 2 groupes (population africanisée ou européenne), dans. le tableau 3 . Quelques probabilités ont été calculées et données dans les tableaux 5 à 12 .

Les outils les plus utiles pour un dépistage initial seraient la longueur de l'aile antérieure et le poids humide. Dans le cas où le poids humide ne peut être déterminé avec précision, le poids sec peut être 
utilisé. La méthode à 2 variables qui donne les meilleurs résultats est celle qui combine la longueur de l'aile antérieure et le poids humide; puis vient en second celle qui combine les longueurs de l'aile antérieure et du fémur, quand on ne dispose que de l'équipement pour mesurer les longueurs. La méthode à 3 variables la plus précise, pour les programmes qui nécessitent une telle précision, utilise la longueur de l'aile antérieure, la longueur du fémur et le poids humide.

\section{ZUSAMMENFASSUNG \\ VERBESSERTE EINFACHE VERFAHREN ZUR BESTIMMUNG AFRIKANISIERTER UND EUROPÄISCHER HONIGBIENEN}

Es wird eine genaue und billige Schnelltechnik zur Unterscheidung zwischen Afrikanisierten und europäischen Honigbienen in den beiden Amerikas beschrieben. Im Vergleich zu einer früheren Version von Rinderer et al. (1986 a) werden bei diesem Verfahren verbesserte Maße und Statistiken benutzt. Bei dieser Methode werden Länge des Vorderflügels, "Feuchtgewicht" (Arbeiterin minus Darm) oder "Trockengewicht» (wie bei Feuchtgewicht, aber durch $24 \mathrm{~h}$ bei $60^{\circ}$ getrocknet) einzeln oder in Kombination benutzt ; oder auch in Kombination mit Femur-(Oberschenkel-) Länge. Die beschreibende Statistik für dieses Verfahren wird in Tab. 1 gegeben. Die Einzelmaße sind in ihrer Diskriminationsfähigkeit wie folgt gestuft : Vorderflügellänge $>$ Feuchtgewicht $>$ Femurlänge $>$ Trockengewicht. Kombinationen unterscheiden noch besser. Das zeigt sich bei der Trennung der Gruppenzentroide in ausgewählten Fällen (Fig. 1).

Acht verschiedene Diskriminanzfunktionen wurden entwickelt um Benutzern die Möglichkeit zu geben, die Messung oder Kombination auszuwählen, die ihren Bedürfnissen oder Möglichkeiten am besten entsprechen. Die Formeln zur Berechnung dieser Funktionen werden in Tab. 2 gegeben und die Formeln zur Berechnung exakter Wahrscheinlichkeiten der Zugehörigkeit zu einer der beiden Gruppen (Afrikanisiert oder europäisch) in Tab. 3. Einige Wahrscheinlichkeiten wurden berechnet und in den Tabellen 5-12 dargestellt.

Vorderflügellänge und Feuchtgewicht erscheinen für eine erstc Überprüfung am geeignetsten. Wo das Feuchtgewicht nicht genau bestimmbar ist, kann das Trockengewicht nützlich sein. Die besten Ergebnisse eines Verfahrens mit zwei Merkmalen erhält man bei einer Kombination von Vorderflügellänge und Feuchtgewicht. Das zweitbeste Verfahren mit zwei Merkmalen, Vorderflügel und Femurlänge, könnte dort eingesetzt werden, wo nur die Einrichtungen zu Längenmessungen zur Verfügung stehen. Das präziseste Verfahren mit drei Merkmalen, für Programme die diese Genauigkeit verlangen, verwendet Vorderflügellänge, Femurlänge und Feuchtgewicht.

\section{BIBLIOGRAPHY}

Carlson D.A., Bolten A.B., 1984. - Identification of Africanized and European honey bees using extracted hydrocarbons. Bull. Entomol. Soc. Amer., 30, 32-35.

Daly H.V., Balling S.S., 1978. - Identification of Africanized honcybees in the Western Hemisphere by discriminant analysis. J. Kansas Entomol. Soc., 51, 857-869.

Daly H.V., Hoflmer K., Norman P., Allen T., 1982. - Computer-assisted measurement and identification of honcy bees (Hymenoptera: Apidae). Ann. Entomol. Soc. Amer., 75, 591-594.

Gary N.E., Daly H.V., Loche S., Race M., 1985. - The Africanized honey bee : ahead of schedule. California Agric., 39, 4-7.

Kendall M.G., Stuart A., 1961. - The Advanced Theory of Statistics, Vol. 3, Charles Griffin and Co. London. 
Rinderer T.E., Sylvester H.A., Brown M.A., Villa J.D., Pesante D., Collins A.M., 1986 a. Field and simplified techniques for identifying Africanized and European honey bees. Apidologie, 17, 33-48.

Rinderer T.E., Sylvester H.A., Collins A.M., Pesante D., 1986 b. - Effect of nurse-bee genotype and comb size on morphometrically based identification of Africanized and European honey bees. Bull. Entomol. Soc. Amer., 32, 150-152.

SAS, 1982. - SAS User's Guide: Statistics. SAS Institute Inc., Cary, North Carolina.

SaTterthwarte F.W., 1946. - An approximate distribution of estimates of variance components. Biometrics Bull, 2, 110-114.

SPSS $^{\mathrm{X}}$, 1982. - SPSS ${ }^{X}$ User's guide. SPSS Inc. Chicago, Illinois.

SylVester H.A., 1982. - Electrophoretic identification of Africanized honeybees. J. Apic. Res., 21, 9397.

TABachnick B.G., Fidell L.S., 1983. - Using Multivariate Statistics. Harper and Row, Inc., New York. 